\title{
ヒト扁桃胚中心での apoptosis
}

— tingible body macrophage を中心に一

川端五十鈴・田部 浩生

\section{An Apoptosis in the Germinal Center of Human Palatine Tonsil}

\author{
Isuzu Kawabata and Hiroo Tabe \\ (Saitama Medical Center, Saitama Medical School)
}

Apoptosis in the human tonsillar germinal center was studied by immunocytochemical methods. It is generally accepted that the germinal center of the lymphoid tissues plays an important role both in cell proliferation and cell death. Although many studies of cell proliferation have been reported, the mechanism of cell death is not yet well understood. According to recent studies, apoptosis indicates programmed cell death, not pathological death, and plays an important role in maintenance, immunity and development of life.

In 1885 , Flemming reported hematoxin-stained dense bodies within the cell in the germinal center and named them tingible bodies.

Subsequent studies showed that the tingible body was a mass of nuclear chromatin from dead cells, and the cell containing tingible bodies was the macrophage, then called the tingible body macrophage.

This study investigated the relationship between tingible body macrophages and apoptosis. Tingible body macrophage and adjacent structures were examined by immunostaining. The results were as follows:

1. H.E. stained section : tingible body macrophage and tingible bodies were clearly shown. Tingible body was a hematoxin-stained granule.

2. Observation of apoptosis : immunostained apoptotic body was shown to be same as tingible body by comparing observations on H.E. stained sections.

3. Observation of macrophage : Tingible body macrophage was clearly observed by the CD68 immunostaining method.

4. Observation of S-100 protein positive cell: S-100 protein positive cells consist of large cytoplasma and long cytoplasmic processes. The latter are intermingled with each other to form a network around the tingible body macrophage.

5. Observation of B-cells : The immunostained B-cell is found near the tingible body macrophage.

6. Observation of T-cells : Immunostained T-cells were found in the germinal center, but did not contact the tingible body macrophage.

We discussed apoptosis of the tonsillar germinal center based on the findings cited above.

Key words : apoptosis, tonsil germinal center, tingible body, macrophage, immunostaining 


\section{はじめに}

Keimzentrum すなわち泼中心は末梢リンパ組織の中 で特異な形態を示す部位である。この胚中心は1885年 Flemming ${ }^{1)}$ がその形態を記載して命名したものであり， その由来は肧中心に多数の細胞分裂像を見出して, 細胞 産生の中心と考光たからである. 同時にこの論文の中で， いわゆる tingible body (可染小体)についても附図をま じえて詳細に記載しているが，その機能については不明 であると述べている. その後の研究で tingible bodyは macrophage によって喰食処理された細胞核の断片であ り, 肧中心で不用となった細胞の処理機能が存在するこ とがわかり, 肧中心はリンパ球の産生部位 (birth place) と同時に死隇部位 (grave yard) の 2 つの機能を孔つ組織

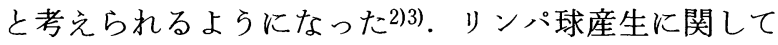
従来から多くの研究が打こなわれてきた。私共も BrdU を用いた免疫細胞学的方法で観察し，報告してき た4)5). 一方 macrophageを中心とする grave yard 説に ついてもいくつかの研究が拈こなわれてきた．1980年 Wyllie ら6)によって提唱された細胞の programmed death は近年 apoptosis の概念に発展し, 生体の細胞調 節機構として一般に認められるようになった．最近， apoptosis を形態学的に研究する方法として免度染色法 が開発され, apoptotic body の検出が可能となった778). 私共はヒト口蓋扁桃の肧中心にみられる macrophage に ついて apoptotic bodyを危疫染色法で観察するととも に，2〜3の免疫細胞学的検討を抏こなったので，その 所見を供覧し，若干の考察を怙こなったので報告する。

\section{研究材料之研究方法}

研究材料: 慢性扁桃炎, 扁桃肥大の診断のもとに扁桃 摘出術を施行した摘出口蓋扁桃を用いた。症例はおの括 の 5 例であり，また慢性扁桃炎症例では手術時に急性増 悪などの急性発症期ではない。

研究方法：摘出口蓋扁桃は直ちに $10 \%$ ホルマリンで固 定，パラフィン包埋切片を作成した. 切片は次の方法で 染色して検鏡した。

1 ) tingible body の観察

通常の Hematoxin-Eosin (HE) 染色標本を用いた.

2) apoptotic body の観察

Oncor 社の Apop Tag キットを用いて免度染色し，検 出した. Wijsman ら ${ }^{8)}$ の方法に順じて10\%中性ホルマ リン固定，パラフィン包埋した試料を用いた. 切片は脱
パラしたあと，前処理として， proteinase $\mathrm{K} て ゙$ 処理した。 洗浄後, terminal deoxy-nucleotidyl transferase (TdT) で処理を扣こない，充分に洗浄後，切片にanti-digoxigenin-peroxidase を滴下して反応させた。その後， $0.05 \%$ diaminobenzidine に $\mathrm{H}_{2} \mathrm{O}_{2}$ を加光た染色液で発 色させて検鏡した。

3 ) tingible body macrophage $の$ 観察

中性ホルマリン固定, パラフィン包埋の試料を用いた. 切片は avidin-biotin 法で免疫染色を打こなった。抗体 はDAKO 社製の anti-human macrophage CD68を用い た。

4 ) S-100 蛋白陽性細胞の観察

中性ホルマリン固定，パラフィン包埋の試料を用いた 切片は peroxidase-anti-peroxidase 法で免疫染色を施し た. 抗 S-100 蛋白ポリクロナール抗体は DAKO 社製の ものを用いた。

\section{5 ) B-細胞の観察}

中性ホルマリン固定，パラフィン包埋の試料を用いた。 切片は peroxidase-anti-peroxidase 法で免疫染色を施し た。抗体はDAKO 社製の anti-human B-cell monoclonal 抗体 CD20，ならびに Euro-Diagnostica 社製の anti-leukocyte monoclonal 抗体 MB1 を用いた.

\section{6 ） T-細胞の観察}

中性ホルマリン固定，パラフィン包埋の試料を用いた. 切片は peroxidase-anti-peroxidase 法で免疫染色を施し た. 抗体は DAKO 社製の anti-human T-cell monoclonal 抗体 CD45RO，ならびに Euro-Diagnostica 社製の anti-leukocyte monoclonal 抗体 MT1 を用いた.

\section{研究成績}

1. 胚中心の細胞組織学的所見

ヒト口蓋扁桃の胚中心は円形あるいは楕円形を呈し， 陰窩上皮の直下に存在する. HE 染色標本で観察すると (図 $1 \mathrm{a}$ ), 濃く染色される暗調部と淡明に染色される明 調部の 2 つに区別される. 前者は小リンパ球が集合した ものであり, 円形の肧中心の中で陰窩上皮側に半月状に 存在するので, リンパ外套あるいは暗殼とよばれる。一 方, 後者は明中心ともいわれ, 肧中心の大部分を占め, 大型のリンパ球, 形質細胞, 細網細胞などよりなり, そ の細胞構成は多彩である.

2 . tingible body macrophage

$\mathrm{HE}$ 染色で淡明に染色される明中心の中で，さらに染 
色性に乏しい部位があり，一見して抜けて無構造のよう にみ光，しかもその形状が不整多角形を呈するので，夜 空に輝く星にたとえられ， starry sky pattern と呼ばれ ている部位が散在性に観察される. starry sky pattern を拡大したものが図 $1 \mathrm{~b}$ (矢頭)である。ここに大きな細 胞があり，細胞質も大きく，細胞核も円形で大きい，核 質は踈であり, 通常 1 個の核小体があり, 核の中心部, あるいは時に辺縁部にみられる．特徵的なことは細胞質 の中にへマトキシリンで濃染される大小不同の顆粒が存 在することである。これが Flemming1)の言う tingible bodyであり，この大型の細胞が tingible body macrophage である (図 $1 \mathrm{~b}$ 矢頭). この細胞は tingible body の数が多い程, 形が大きくなる傾向にあった. tingible body macrophage に接して核が pyknosisを抗こしたり ンパ球，あるいは細胞核と思われる濃染する小体を数個 もつ細胞がみられた。

3. 肧中心に打将る apoptosis

図 $2 \mathrm{a}$ は図 $1 \mathrm{a}$ の隣接切片で, しかも図 1 で示した同 じ肧中心の apoptosis の所見を示した. 本免疫染色法で は核が破壊され，クロマチンが濃縮した apoptotic bodyは暗褐色の小体として観察される. HE 染色標本 (図 $1 \mathrm{a}$ ) と比較してみると, apoptotic bodyは肧中心に あり, また泼中心の中では暗殼にはなく, 明中心に存在 する．そして明中心の中では全体にわたって散在性にみ られる。拡大してみると(図 $2 \mathrm{~b}$ ) 暗褐色の apoptotic body は円形の顆粒状であり，大きさは大小不同である. また強く反応して強く染色反応を示すもの，あるいは染 色程度が弱いものなどある. 小型の方が染色反応の強い 傾向が見られた．多くの場合， apoptotic bodyのまわり は空胞状に抜けてみ兄る。そしてこの空胞状の中に 1 個, あるいは数個の apoptotic body が見られる. HE 染色標 本と比較検討すると, apoptotic bodyは tingible body に相当するものと思われる.

4. 肧中心の macrophage の免废染色所見

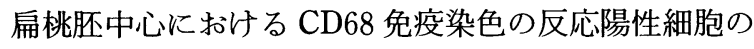
所見を図 3 a に示した. 反応陽性細胞は暗殼にはなく, 明中心にのみ見られた。 また明中心でも暗殼に接する部 位では少ない，拡大してみると(図 $3 \mathrm{~b}$ ), 反応陽性細胞 は隣接の細胞に比べて大きく，円形ないしは，楕円形を 呈するが，不整多角形のものもある. 核は染色されず， 細胞質が反応陽性であるが，時に空胞状に無反応の部位 がある.CD68 免疫染色陽性細胞は肧中心内の分布状態,
細胞の形状から macrophage, いわゆる tingible body macrophage と相当するものである。しかし， starry sky patternを示寸部位にある細胞でこの反応を示さな いものも散見された.

5 . 胚中心内の S-100 蛋白陽性細胞

扁桃組織内での S-100 陽性細胞は陰窩上皮, 濾胞間領 域, 泼中心など広く分布している. 泼中心内の分布の様 子を図 4 a に示した．S-100 陽性細胞は暗殼では小リン 八球の間に極くま机に存在する。この細胞は円形を呈し， 細胞突起はなく，また比較的大きな核をもっていた．明 中心内での陽性細胞は暗殼直下には少なく，その他の部 位では広く分布していた．陽性細胞の強拡大像を図 $4 \mathrm{~b}$ に示した。本法では細胞質, 細胞突起や細胞核も免疫染 色されるので，細胞の形態がよくわかる．核は円形ある いは棈円形を呈し，比較的大型であり，その中央部に核 小体が存在する，細胞質は核に比べて狭く，細胞突起を 周囲にのばしている．突起は単極性，あるいは双極性の ことが多いが，時に多極性にみえる場合もある．として 細胞突起は抢たがいに吻合様に連絡しあい網目状構造を 形成している。従来の研究9) 11) から S-100 陽性細胞は follicular dendritic cell と考光られた. そしてその細胞 突起は反応陰性の tingible body macrophage をとりか こみ, 網目状構造の目の所に tingible body macrophage が存在した。しかし時には細胞自体が tingible body macrophage に接している所見もみられた.

6. tingible body macrophage 周辺のリンパ球 tingible body macrophage の周辺には多数のリンパ球 が存在する。これらのリンパ球の同定を抗こなった。 $\mathrm{B}$-リンパ球の証明にはモノクロナール抗体 $\mathrm{CD}_{20}$ と $\mathrm{MB}_{1}$ の 免疫染色を用いた．反応陽性細胞は胚中心の明中心ばか りでなく，暗殼にも多数認められた(図 $5 \mathrm{a}$ ). 明中心を 拡大してみると (図 $5 \mathrm{~b}$ ), 反応陽性細胞は tingible body macrophage の存在する starry sky pattern に接して多 数認められた。一方, T-リンパ球の同定にはモノク口 ナール抗体 CD45 UCHL-1 と MT1 を用いた。 反応陽性 細胞は肧中心の明中心にも暗殼にも認められたが，その 数は極めて少なかった(図 $6 \mathrm{a}$ )。明中心を拡大したもの を図 $6 \mathrm{~b}$ に示した。 反応陽性細胞は散在性にみられたが (図 $6 \mathrm{~b}$, 矢印), tingible body macrophage の周辺に及 られることはまれであった。 

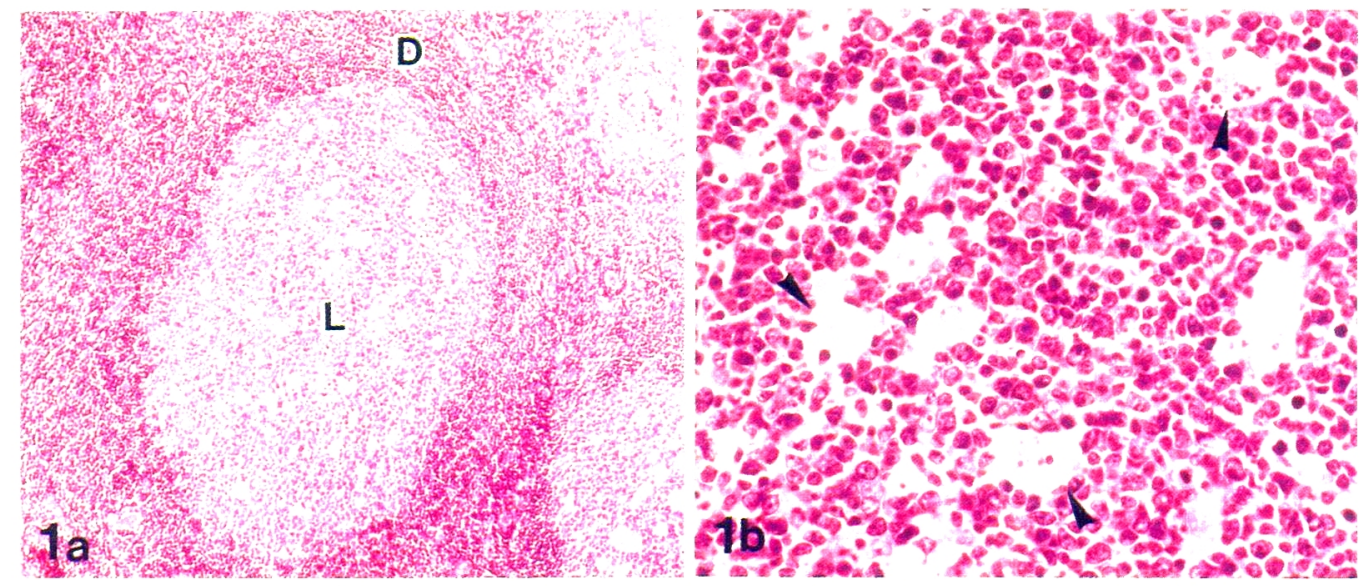

D
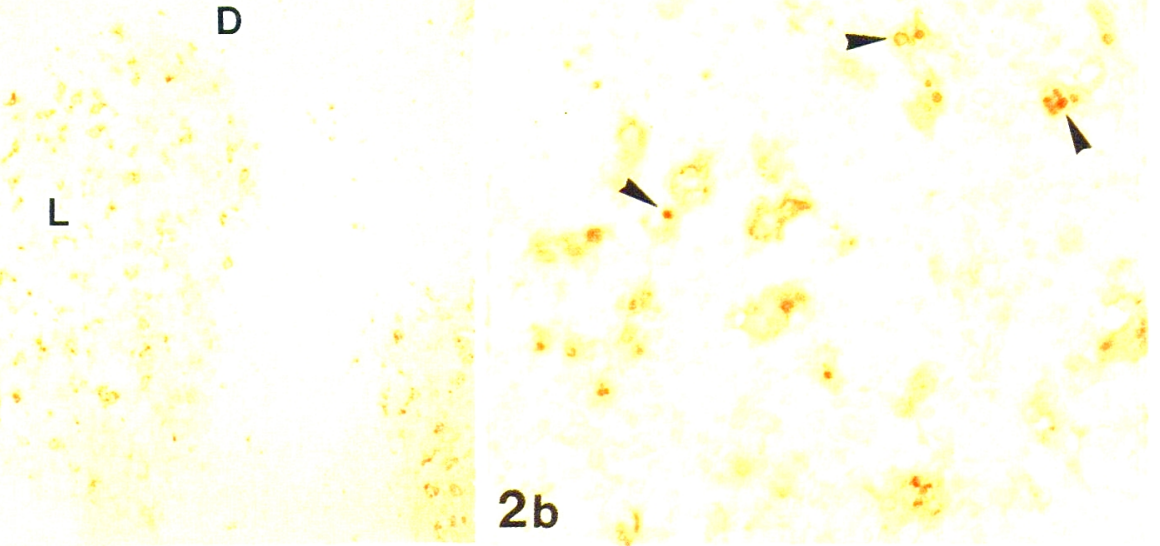

$2 a$

$2 b$
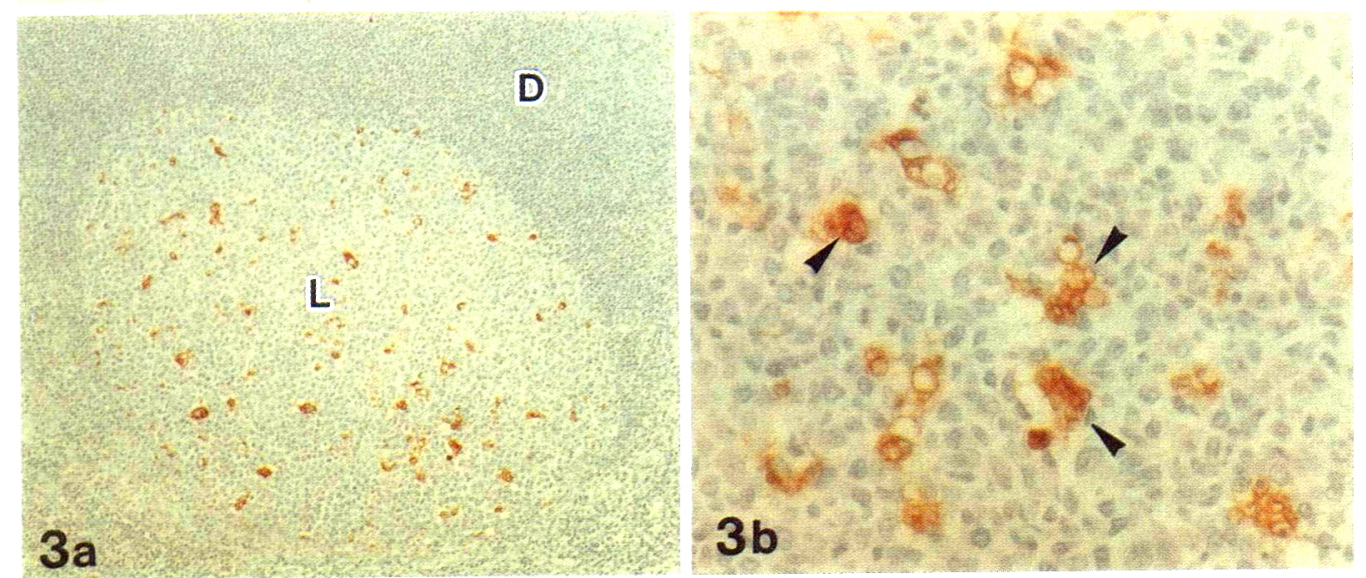

図 1 扁桃胚中心 $(\mathrm{HE}$ 染色)

扁桃胚中心は円またはダ円形で，小リンパ球より構成される暗調の暗穀 (D) と中央部の明調の明 中心 (L)より成る。明中心ではさらに染色性の低部分が散在し, starry sky pattern を示与(図1 a 弱拡大). 図 1 b は明中心の強搪大像で starry sky pattern $の$ tingible body macrophage 走示吉. tingible body 有寸る macrophage も又られる(短)。

図 2 肧中心 0 apoptosis

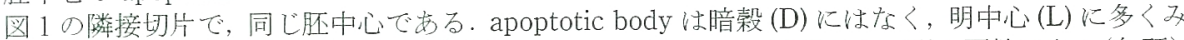
られる(図 $2 \mathrm{a}$ 弱桩大). 図 $2 \mathrm{~b}$ 治桩大像で, apoptotic bodyは暗褐色の円形の顆粒である(矢頭)

図 3 肧中心の macrophage

CD68 免疫染色反応陽性の macrophage 愔穀 (D) に怆な，明中心 (L) 飞存在している (図 3 a 弱桩大)。図 3 b (矢頭). 


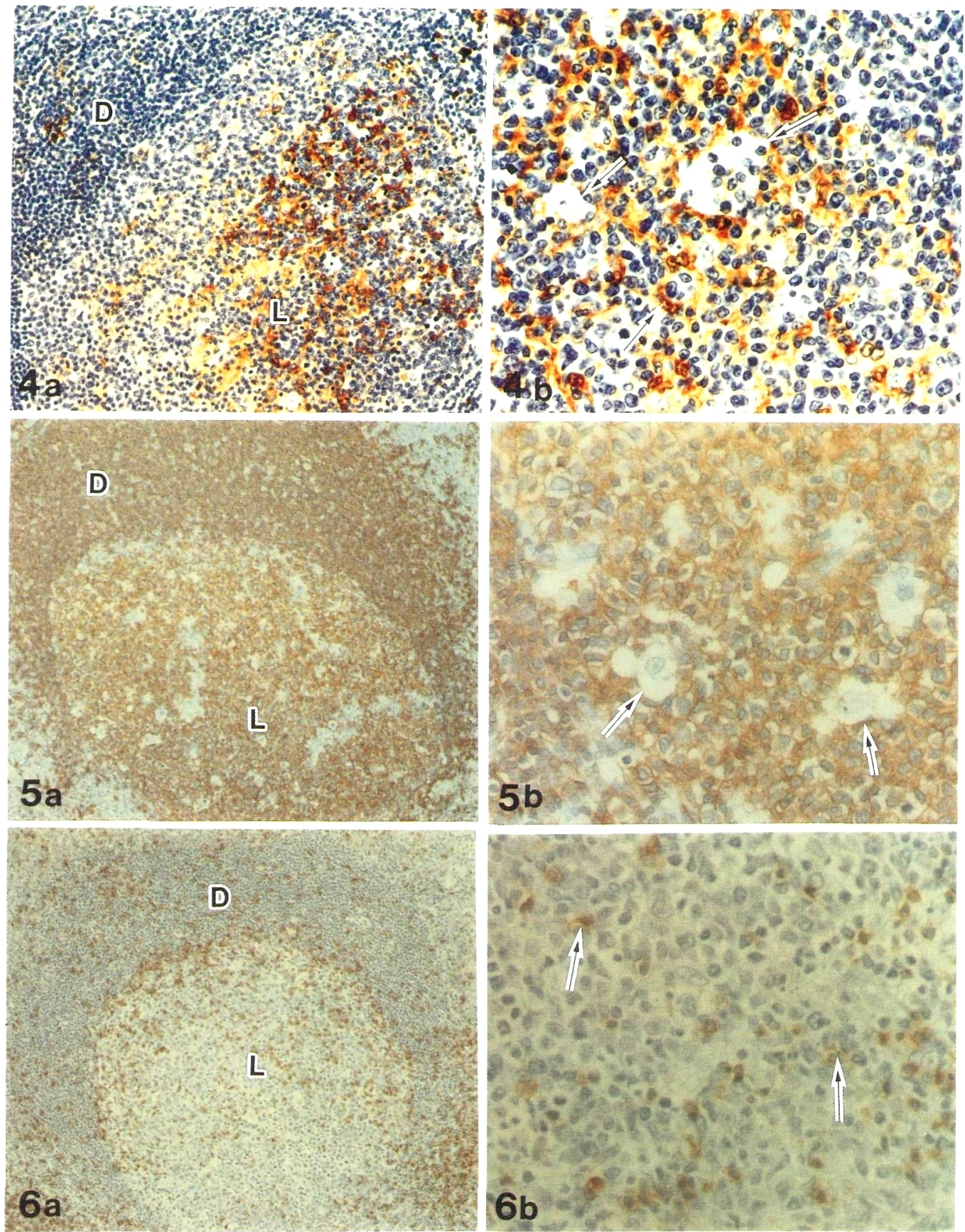

図 4 肧中心の S-100 蛋白陽性細胞

陽性細胞は暗穀 (D) には少なく，明中心(L) 飞広く分布している(図 4 a 弱拡大)。図 $4 \mathrm{~b}$ は強拡 大像で，明中心の陽性細胞は細胞質より細胞突起学出し，細胞突起は特たがいに吻合して網目状 構造をなし，網目状の目の所に tingible body macrophage がみられる(矢印)。

図 5 肧中心のB-細胞の分布 B-細胞は暗穀 (D) にも明中心 (L) 飞も広く分布している(図 $5 \mathrm{a}$ 弱拡大)。図 $5 \mathrm{~b}$ は強拡大像で, tingible body macrophage の周辺に多数存在している(矢印)。

図 6 肧中心の T-細胞の分布

T-細胞は B-細胞にくらべて暗穀 (D) と，明中心 (L) ともに分布は少ない(図 6 a 弱桩大)。図 6 b は強拡大像で, 明中心の中の T-細胞は tingble body macrophageの周辺には少ない(矢印). 


\section{考案

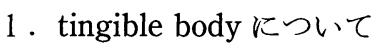

リンパ組織の泼中心はリンパ球の産生部位であると同 時に細胞の死滅の部位でもあるとされている．肧中心内 で生じる細胞死は1885年 Flemming ${ }^{1)}$ の tingible body の 観察によってはじまる. Flemming は肧中心の中のある 種の細胞質中に独特の形状を呈し，濃染する顆粒を見出 して tingible body (可染小体)と名づけた。そしてこの 小体は形状, 大きさ，あるいはアニリン染色性から色素 顆粒と明確に区別でき，また細胞分裂休止期の細胞質内 にあり，分裂期のものにはみられないとし，さらにこの 小体の本態や生理的な意義は不明であると報告した.

以後 tingible body について多くの研究がおこなわれ， tingible bodyは macrophage に喰食された細胞の核の 断片で, 染色体の凝集したものであり, 肧中心内で不要 となった細胞の処理機能と考えた. そこから肧中心は細 胞産生部位と同時に細胞の grave yard 説233) が提唱され た. そして胞体内に tingible bodyをもつ macrophage を特に tingible body macrophage の名称でよばれてい る. 近年この細胞は電顕でも観察され, 喰食される細胞 はリンパ球, 形質細胞, 顆粒球, あるいは赤血球などで あり 12) 16), この細胞のもつ細胞処理機能の重要性がう かがえる。

2. apoptosis Kついて

最近, 生体内で生じる病的な細胞死でなく, 細胞の自 殺死，あるいは遺伝子に組及込まれた細胞死 (programmed death) という apoptosis の概念が Wyllie ら'6) によって提唱された. apoptosis は単なる細胞の死滅で はなく，生体の成長や生体の恒久性維持にとって重要な 生体の制御機構と考穴られるようになった。

肧中心は前述の如く, 細胞死の grave yard であり, tingible body macrophage がその主体をなしている。扁 桃の胚中心では tingible body macrophage が容易に観 察できるので, apoptosis を研究するのに最適な研究材 料と思われる.

最近 apoptosis の形態学的な検出が免疫細胞学的方法 で可能になった778). apoptosis の最終段階では細胞核内 部の溶解がおこり, 染色体の分解によって DNA の断片 化を生じる．そして $\mathrm{Ca}^{2+} \mathrm{Mg}^{2+}$ 依存の endonuclease に よってさらにDNAは分割され，最後にはnucleosome の大きさの DNA フラグメントとなる. 今回用い た Apop Tag 法では DNA フラグメントの末端に生じた
3-OH を標識目標とするものである. terminal deoxy-nucleotidyl transferase の作用によって digoxigenin を 3$\mathrm{OH}$ に付加したあと，抗 digoxigenin 抗体フラグィント を反応させ，さらに抗 peroxidase を共用結合させ，そ のあとでDNBで発色させて apoptosisをみる方法であ る、本法は壊死などによって生じる DNA フラグメント では染色することは少ないとされて括り7，またホルマ リン固定，パラフィン包埋の試料でも使用できる簡便さ がある8)ので，今回の実験に用いた。

$\mathrm{HE}$ 染色された隣接切片と比較すると(図 $1 \mathrm{a}$ と図 2 a)，胚中心の明中心のいわゆる starry sky pattern に対 応して apoptosis の反応がみられ，また強拡大像でみる と, apoptotic body が顆粒状に免疫染色されて確認でき た。

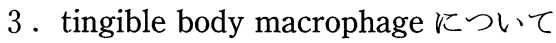

tingible body macrophage 9 同定に CD68 (DAKO 社) の monoclonal 抗体免疫染色を用いた. CD68 の免疫染 色は最近, 凍結切片標本ばかりでなく, パラフィン包埋 切片でも可能となり，また後者の方が検出にすぐれ，染 色性がよいといわれている11)ので使用してみた．CD68 抗体は lysosome 顆粒と関係ある細胞内物質と関連して いるものとされるので, この免疫染色では脾藏, 肝臓, 肺，骨䯣などの macrophage が反応するが，しかしinterdigiting cell や follicular dendolitic cell は染色されな い17)。したがって肧中心の明中心のように細胞構成の複 雑な部位での macrophage の形態を観察するのに適して いると思われる. 今回の観察で反応陽性細胞は不整多角 形を示す大型の細胞で, 細胞質全体が染色される. また 細胞質内には大小不同の空胞がみられる. また存在部位 はいわゆる starry sky patternの中にみられるものであ り, tingible body macrophageをよく表現していると思 われた。

今回の所見で少数ではあるが，小型の，括そらく小リ ンパ球にも免疫染色されるのがみられた. Falini ら CD68 は活動性のリンパ節に存在する monocyto/ macrophage origin と考えられる plasmacytoid T-cell に も反応して染色されると報告しているので今回私共が観 察した CD68 反応陽性の小型細胞は macrophage とはま た別の細胞であろう。

4. S-100 陽性反応細胞について

S-100 蛋白は Moore ${ }^{18)}$ によりウシ，ブタおよびウサギ の脳組織より分離されたカルシウム結合性酸性蛋白質で 
ある。この蛋白質は全身諸蔵器にも存在し，免疫系組織 ではリンパ節, 胸腺, 脾臓ばかりでなく扁桃組織に存在 して拉り，扁桃組織では肧中心に括ける存在が注目され る.

胚中心における S-100 蛋白陽性細胞は大型の核をもち， 細長い細胞突起をもった細胞である. そして図 4 に示す ように細胞突起を周囲にのばし，相互に連絡しあって網 目状構造を形成するのが特徽である919)201，近年，末梢 リンパ組織の恒久性を維持するものとして 4 種類の細胞, すなわち histiocyte (単球系または macrophage 系の細 胞), interdigitaiting reticulum cell (IRCs), follicular dendritic reticlum cells (DRCs) と fibroblastic reticulum cell (FRCs)がある20). histiocyte と IRCs は血液，リンパに 由来する細胞であるが， DRCs と FRCs はリンパ組織本 来の細胞と考兄られている. DRCs と FRCs 両者の区別 は光顕や電顕所見から扣こなわれていたが，最近は免疫 染色による方法が用いられている．DRCs は S-100 蛋白 陽性で，FRCs はビメンチン陽性であり9) 11119)20)，した がって今回観察された胚中心の S-100 蛋白陽性細胞は DRCs に相当するものである.

S-100 蛋白陽性細胞の胚中心内の分布は暗殼にはなく, 明中心が主である．私共の観察では明中心の中央部から 底部(暗殼との対側)にかけて多く存在した。 反応陽性細 胞の細胞突起で形成される網目状構造の網目の穴にしば しば tingible body macrophage が存在して拉り, した がってこの細胞をとりまくように網目状構造があるばか りでなく，時に大きな核をもった細胞質そのものが直接 に tingible body macrophage に接している所見もみら れた. DRCs の機能として免疫複合体の結合能，正常あ るいは腫瘍性のリンパ球の補促能が報告されてい

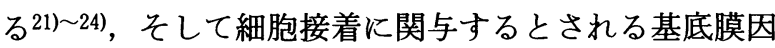
子であるラミニン25226) の存在が報告されているので，S100 陽性反応の DRCs は tingible body macrophage の働 きに重要な役割をはたしていると思われる.

5 . tingible body macrophage に隣接する細胞 tingible body macrophage の周辺の構成細胞をみるた め，免疫染色法によってリンパ球の同定を扣こなった。 明中心には T-リンパ球は少なく, B-リンパ球が多数存 在し, tingible body macrophage 飞接している場合もあ った．扁桃の免疫機能を相当するリンパ球は液性免疫に 関与する B-リンパ球と細胞性免疫に重要な T-リンパ球 に大別され，両者を識別し，組織内での両者の局在を知
ることは免疫機構を解明するのに重要である．組織切片 標本の上で，B-リンパ球，T-リンパ球の同定に関する 研究としては $\gamma$-グロブリン局在を虽光抗体法で観察す る方法27) 以来，口ゼット形成法，酵素抗体法などがあ る. 近年免疫組織細胞学の発展にともないモノクロナー ル抗体の開発がすすめられ, リンパ球の $\mathrm{T} ・ \mathrm{~B}$ の分類に 応用されている。

今回私共が B-リンパ球同定に用いた抗ヒト B-細胞モ ノクロナール抗体 $\mathrm{CD}_{20}-\mathrm{L}_{26}$ は多くの $\mathrm{B}$-リンパ球に存在 する抗原に対応するものであり，その抗体は B-細胞に 存在する $33 \mathrm{KD}$ のポリペプタイドと反応する2829)。そし てこれは末梢血液やリンパ組織内の大部分の B-リンパ 球と反応するとされるので，使用した．図 5 にみられる ように本法で免疫染色される B-リンパ球は肧中心に多 く認められ, 明中心では tingible body macrophage の 周辺に認められた。

末梢の B-リンパ球は T-リンパ球よりも積極的に apoptosis に関与しているとされている30131)。すなわち，Bリンパ球は末梢に出てからもレセプターの遺伝子を突然 変異により変化させる機構を有しているために, apoptosis が生じる必要性があると考えられている．多田 ${ }^{311}$ によると，二次リンパ小節の胚中心の明中心で分裂，増 殖した幼若なB-リンパ球はレセプターを発現し，分化 しながら暗殻に向けて移動する。この時に抗原を認識で きた B-リンパ球は生き残るためのシグナルを受け取っ て, 記憶 B-リンパ球となるが，これに反し，抗原に反 応しなかった B-リンパ球は apoptosis によって死隇する と考觉られている。そしてLiu ら ${ }^{32)}$ は，このようにレ セプターの突然変異によって抗原に親和性を高める生存 機構が存在すると共に, 抗原と反応できない細胞の存在 は生体にとって不利であり, 生体から除去する機構が apoptosis の役割と考㝋ている。しかし幼若な B-リンパ 球から成熟した記憶細胞の分化の過程で，どの段階の細 胞が apoptosis に関与するのか，あるいは tingible body macrophage の周辺にみられた B-リンパ球は分化の段階 のどの細胞に属するかを知ることは重要であり, 今後の 課題であろう.

\section{結 語}

リンパ組織の胚中心は細胞の産生と細胞死隇の処理を おこなっている部位であり，後者は tingible body macrophage が関与するといわれてきた. 近年, 細胞の 
死は病的なるのばかりでなく，遺伝子によってプログラ ムされた細胞の死といら apoptosis が提唱された. apoptosis は生体の細胞の制御機構として重要な作用とされ た. 最近, apoptosis を形態学的に観察するために，免 疫染色で apoptotic bodyを検出する方法が開発された のでこの方法を用いて，ヒト扁桃肧中心の apoptotic bodyを観察し, tingible body との関係，あるいは, tingible body macrophage の周辺の構成細胞を免疫染色 で観察し，以下の結果を得た。

1. HE 染色での観察 : tingible body と tingible body macrophage の所見を示した.

2. 免疫染色による apoptotic body の観察 : tingible body は apoptotic body と同じものであることを示した.

3. 免疫染色による macrophage の観察：CD68 に上 る免疫染色で macrophage を同定した.

4. S-100 蛋白陽性細胞の観察：macrophage 周辺に ある S-100 蛋白陽性細胞は follicular dendritic cell であ ることを示した.

5. 免疫染色によるB-細胞の観察 : macrophage 周辺 のリンパ球は主として B-細胞であることを示した.

6. 免度染色による T-細胞の観察： T-細胞と macrophage の直接の接触のないことを示した.

7. 以上の所見から扁桃胚中心の apoptosis の意義に ついて文献を引用しながら若干の考察をおこなった。

本研究は文部省科学研究費補助金 (平成 6 年一般研究 C06671731)の援助をうけた. 免疫染色研究にあたり当院共同研 究室の青木志津子氏の協力に感謝する。

\section{文 献}

1) Flemming $W:$ Studien uber regeneration der gewebe. Arch Mikr Anat $24:$ 50 91, 1885.

2 ) Heiberg KA : Uber die Phagocytosecentra des Lymphoid Gewebs und uber die Lymphocyten Produktion. Acta Med Scand 65 : 443 460, 1927.

3 ) Ehrich $W$ : The role of the lymphocyte in the circulation of the lymph. Ann NY Acad Sci $46: 823 \sim 857,1946$.

4) Kawabata I, Nakamura $M$ and Tabe H : Functional morphology of tonsillar germinal center. Adv Otorhinolaryngol $47: 46 \sim 50,1992$.

5 ）川端五十鈴, 田部浩生，中村雅一：ヒト口蓋扁桃肧中心の 細胞動態. 日扁桃誌 32：25～30, 1993.

6) Wyllie AH, Kerr JR and Currie AR : Cell death; the significance of apoptosis. Int Rev Cytol 68 : 251 306, 1980.
7) Thiry M : Highly sensitive immunodetection of DNA on section with exogenous terminal deoxynucleotidyl transferase and non-isotopic nucleotide analogs. J Histochem Cytochem $40:$ 411 419, 1992.

8 ) Wijsman JH, Jonker RR, Keijzer R, et al : A new method to detect apoptosis in paraffin section in situ endlabeling of fragmented DNA. J Histochem Cytochem 41 : 7 12, 1993 .

9 ) Carbone A, Polelte A, Manconi R, et al : Demonstration of S-100 protein distribution in human lymphoid tissues by the avidin-biotin complex immunostaining method. Hum Pathol 16 : 1157 1164, 1985.

10）川口 誠, 右沢 伸, 霜田ゆ久, 他：扁桃組織内 S-100 蛋 白陽性細胞の免疫組織学的検討. 日扁桃誌 $29: 60 \sim 65$, 1990.

11) Gloghini $A$ and Carbone A: The nonlymphoid microenvironment of reactive follicles and lymphomas of follicular origin as defined by immunohistology on paraffinembedded tissues. Hum Pathol 24 : 67 76, 1993.

12) Swartzendruber DC and Congdon CC : Electron microscope observation of tingible body macrophages in mouse spleen. J Cell Biol 19 : 641 644, 1963.

13) Muller-Hermelink HK and Caesar R : Elektromen Mikroskopische Untersuchung der Keimzentrium in Menschlichen Tonsillen. Z Zellforsch 96 : 521 547, 1969.

14) Hoefsmit ECM, Kamperdijk EWA, Hendricks HR, et al : Lymph node macrophages. The Reticulendothelial System Vol. 1 (ed by Carrand I and Daems WT). pp 417 468, Plenumpress, New York, 1980.

15）小鴆 瑞：リンパ節の細胞病理学的研究 一特に 2 次小節 を中心として一. 日病会誌 $58: 3 \sim 29,1969$.

16) Okato $S$, Magari $S$, Yamamoto $Y$, et al : An immuno-electron microscopic study on interactions among dendritic cells, macrophages and lymphocytes in the human palatine tonsil. Arch Histol Cytol $52: 231 \sim 240,1989$.

17) Falini B, Flenghi L, Pileri S, et al : PG-M1; a new monoclonal antibody directed against a fixative-resistant epitope on the macrophage-restricted form of the CD68 molecule. Am J Pathol 142 : 1359 1372, 1993.

18) Moore BW : A soluble protain characteristic of the nervous sytem. Biochem Biophy Res Commun 19 : 739 744, 1965.

19）山本祐三, 岡東周一郎, 和田公平, 他：扁桃組織内 $T$ zone 組織球の分布樣式と意義について。 日扁桃誌 $25: 127$ $\sim 138,1986$.

20) Gloghini A, Volpe R and Carbone A : Vimentin immunostaining in fibroblastic reticulum cells within human reactive and neoplastic lymphoid follicles. Hum Pathol 21 : 792 798, 1990. 
21) Stein H, Gerdes J and Mason DY : The normal and malignant germinal centre. Clin Lab Haematol $11: 531 \sim 559$, 1982.

22) Gerdes J, Stein H, Mason DY, et al : Human dendritic reticulum cells of lymphoid follicles ; their antigenic profile and their identification as multinucleated giant cells. Virchows Arch Cell Pathol 42 : 161 172, 1983.

23) Heinen E, Lilet-Leclercq G, Mason DY, et al : Isolation of follicular dendritic cells from human tonsils and adenoids ; II. immunocytochemical characterization. Eur J Immunol $14: 267 \sim 273,1984$.

24) Lilet-Leclercq C, Radoux D, Heinen E, et al : Isolation of follicular dendritic cells from human tonsils and adenoids ; I . procedure and morphological characterization. J Immunol Methods $66: 235 \sim 244,1984$.

25) Gloghini A, Golombatti A, Bressan G, et al : Basement membrane components in lympoid follicles; immunohistohemical demonstration and relationship to the follicular dendritic cell network. Hum Pathol 20 : 1001 1007, 1989.

26) Gloghini A and Garbone A : Dendritic reticulum cellrelated immunostaining for laminin in follicular and diffuse B-cell lymphomas. Virchows Arch A Pathol Anat
Histopathol $416: 197 \sim 204,1990$.

27) Ortega LG and Mellors RC : Cellular sites of formation of gammer globulin. J Exp Med $106: 627 \sim 654,1957$.

28) Carlun RW, Coles FB and Pastuszak WT : Ultilization of monoclonal antibody L26 in the indentigication and confirmation of B-cell lymphoma. Am J Pathol 124 : 415 421, 1987.

29) Mason DY, Comans-Bitler WM, Cordell JL, et al : Antibody $\mathrm{L} 26$ recognizes an intra cellular epitope on the Bcell-associated CD20 antigen. Am J Pathol 136 : 1215 $1222,1990$.

30）鍔田武志 : B-リンパ球の選択とアポトーシス. 実験医学 $11: 2281 \sim 2286,1993$.

31）多田隈卓史：リンパ球とアポトーシス. 蛋白質核酸酵素 $38:$ 109 113, 1993.

32) Liu Y-J, Johnson GD, Gordon J, et al : Germinal centres in T-cell-depended antibody responses. Immunol Today $13: 17 \sim 21,1992$.

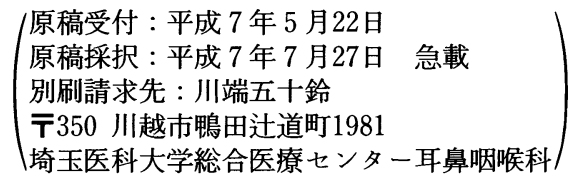

